\title{
The NEBIE plot network: Background and experimental design
}

\author{
by F. Wayne Bell ${ }^{* 1}$, Margo Shaw ${ }^{2}$, Jennifer Dacosta ${ }^{1}$ and Steven G. Newmaster ${ }^{3}$
}

\begin{abstract}
The Intensive Management Science Partnership: NEBIE Plot Network is a stand-scale, multi-agency research project designed to compare the ecological effects of a range of silvicultural treatments in northern temperate and boreal forest regions of Ontario. The NEBIE plot network was established in 2001 with randomized complete block experiments installed at eight sites. The NEBIE acronym stands for Natural disturbance, and Extensive, Basic, Intensive, and Elite silviculture. Each NEBIE treatment was replicated at least three times at each site, using large experimental units (2-ha plots).

The NEBIE plot network provides researchers with an opportunity to conduct long-term scientific studies at multiple scales and disciplines. The operational-scale treatment plots allow assessment of a variety of forest values in a context directly relevant to informing forest planning and management. In this paper, we document the experimental design and describe the sites and silviculture treatments. Information about sampling designs is provided, along with preliminary results, in a companion paper published in this edition of The Forestry Chronicle.
\end{abstract}

Keywords: forest research, silviculture, sustainable forest management

\section{RÉSUMÉ}

Le réseau de placettes NEBIE de l'Intensive Management Science Partnership (partenariat scientifique sur l'aménagement intensif), est un projet de recherche à léchelle du peuplement regroupant plusieurs organismes et destiné à comparer les effets écologiques d'une gamme d'interventions sylvicoles dans les régions tempérée et boréale de l'Ontario. Le réseau de placette NEBIE fut mis en place dès 2001 et comporte des dispositifs expérimentaux en blocs aléatoires complets situés à huit endroits différents. L'acronyme NEBIE signifie Natural disturbance, and Extensive, Basic, Intensive, and Elite silviculture (Perturbations naturelles, traitements de sylviculture extensifs, primaires, intensifs et élite). Il y a au moins trois répétitions pour chaque traitement NEBIE sur des blocs expérimentaux importants (placettes de 2 ha).

Le réseau de placettes NEBIE donne aux chercheurs la possibilité de réaliser des études qui sétendent sur de longues périodes de temps à plusieurs échelles et englobant une multitude de disciplines. Les placettes de traitement à léchelle opérationnelle se prêtent bien à lévaluation d'une variété de valeurs forestières dans un cadre particulier qui aidront à apporter des réponses aux questions des planificateurs et des aménagistes. Cet article présente les dispositifs expérimentaux, les stations ainsi que les interventions sylvicoles. On trouvera plus de renseignements sur le plan expérimental et les résultats préliminaires dans un autre article de ce numéro du The Forestry Chronicle.

Mots-clés : recherche forestière, sylviculture, aménagement forestier durable

\section{Introduction}

In ecology, large-scale, long-term experiments are considered an essential means for advancing science and improving policies and management (Carpenter 1998). Relevant spatial and temporal contexts are designed into such experiments; thus, results can be directly interpreted at appropriate spatial and temporal scales of management (Carpenter 1998). Largescale plots help ensure that treatments more closely emulate forest operations and long-term assessments ensure that slow dynamics, high variability, subtle processes, and complex phenomena are accounted for (Franklin 1989).

During the past three decades, several long-term studies were initiated in northern temperate and boreal forests in response to contentious resource management debates such as clearcutting and herbicide use. For example, the Fallingsnow Ecosystem Project was initiated in 1993 to com- pare conifer release alternatives in response to concerns about aerial application of herbicides in Ontario (Lautenschlager et al. 1998). The Ecosystem Management Emulating Natural Disturbance (EMEND) project, started in 1998, is a large-scale variable retention harvesting experiment designed to test effects of residual forest structure on ecosystem integrity and forest regeneration at forest stand-scale in response to concerns about lack of structural diversity following clearcutting (Volney et al. 1999). The Stand Level Adaptive Management (SLAM) project, initiated in 2001, is another example of a large-scale variable retention harvest experiment. SLAM was designed to develop sustainable mixedwood practices in boreal forests (MacDonald et al. 2003). More recently, Urli et al. (2017) studied a large plot network using the NEBIE framework (Bell et al. 2008) to classify harvesting and silvicultural treatments into silviculture intensities. Their study

\footnotetext{
${ }^{1}$ Ontario Forest Research Institute, Ontario Ministry of Natural Resources, Sault Sainte Marie, Ontario; ${ }^{\star}$ corresponding author: wayne.bell@ontario.ca

${ }^{2}$ Manitoba Environmental Industries Association (MEIA), Winnipeg, Manitoba

${ }^{3}$ Centre for Biodiversity Genomics, Biodiversity Institute of Ontario (BIO), University of Guelph, Guelph, Ontario
} 
was originally established to determine the effects of careful logging around advanced growth. In addition to these operational studies, numerous smaller-scale studies, such as the International Diversity Experiment Network with Trees (IDENT) (Tobner et al. 2014), were initiated to advance knowledge about specific aspects about forest practices on forest ecosystems. Although many studies have been conducted and the results published in the literature, considerable uncertainty remains about the effects of intensification of silviculture (Bell et al. 2000).

In the late 1990s, a need for a large-scale, long-term study to determine the effects of intensification of silviculture in northern temperate and boreal forests of Ontario was identified. This need was identified after the Ontario government expanded its network of parks and protected areas. Intensive forest management (IFM) was proposed as a means to offset the loss of fibre production resulting from the withdrawal of land available for forestry (OMNR 1999, OFAAB 2002). Concerns were raised about conservation of biological diversity, maintenance of productive capacity and forest ecosystem health and vitality, conservation and maintenance of soil and water resources, and maintenance and enhancement of longterm multiple socio-economic benefits, and the feasibility of sustaining these multiple values under an intensive forest management program (see Bell et al. 2000). These concerns echoed those raised in other jurisdictions. For example, Roberts and Gilliam (1995) suggested that experiments should be established to predict the effects of silvicultural practices on species diversity to identify treatments that could lead to localized plant extinctions.

A careful analysis of reviews by Kimball and Hunter (1990) and Lieffers et al. (2003) will reveal that many studies have been conducted to determine the effects specific silviculture treatments (e.g., site preparation, vegetation management, or thinning) on forest ecosystems but not silviculture intensities per se. To date, very few studies have been specifically designed to test the effects of intensification of silviculture on northern temperate and boreal forest ecosystems. Fu et al. (2007) and Wang and Chen (2010) studied the effects of intensification of silviculture on fibre production and tree diversity, respectively, using data from $20 \mathrm{~m} \mathrm{x} 20 \mathrm{~m}$ plots. Thus, knowledge about the effects of intensification of silviculture on forest ecosystems has remained elusive.

In this paper we provide background information about the Intensive Forest Management Science Partnership: NEBIE plot network. NEBIE is a medium-scale, long-term experiment designed to improve our knowledge about the effects of intensification of silviculture on northern temperate and boreal forest ecosystems. More specifically, we (i) provide the rationale for the study, (ii) describe the experimental, treatment and plot designs, and (iii) document background information about each of the study sites. In the following paper (i.e., Bell et al. 2017) we provide highlights of long-term scientific studies.

\section{The NEBIE Plot Network Background}

In 2001, in response to a knowledge gap about the effects of intensification of silviculture on northern temperate and boreal forest ecosystems, the Ontario Ministry of Natural Resources and Forestry (OMNRF), forest industries, the
Canadian Forest Service (CFS), non-governmental organizations, universities, and forest industries partnered to design and implement the NEBIE plot network. This network is a stand-scale, multi-agency, experimental research project designed to improve understanding of the effects of intensification of silviculture on the overall sustainability-long-term health, diversity, and vigour-of northern temperate and boreal forests.

The NEBIE plot network is, to our knowledge, the only experimental project specifically designed to determine the effect of a range of silviculture intensities on northern temperate (commonly referred to as Great Lakes-St. Lawrence) and boreal forest ecosystems. The NEBIE plot network was initiated after a review of international conventions as well as Ontario forest policies and discussion papers, the Crown Forest Sustainability Act, Timber Class Environmental Assessment, Ontario Forest Accord, and proceedings of the IFM science workshop (Bell et al. 2000). The NEBIE acronym refers to the intensity of the silvicultural treatments, Natural (unharvested) and, in order of increasing stocking levels from $40 \%$ to $80 \%$, Extensive, Basic, Intensive, and Elite (Bell et al. 2008) as described in Table 1.

The goal of the NEBIE plot network is to reduce uncertainty related to managing emerging issues including: (1) maintaining or enhancing fibre quantity and quantity; (2) enhancing carbon sequestration; (3) maintaining forest ecosystem health and vitality and soil and water resources; (4) conserving biological diversity; (5) maintaining or enhancing stand composition and structure for wildlife habitat; (6) reducing the risk of losses to natural disturbances (fire, herbivory, insect, disease, and severe weather); and, (7) maintaining or enhancing long-term multiple socio-economic benefits to meet the needs of society. The objectives of the NEBIE plot network are to:

- Determine the effects of natural disturbances and silvicultural practices on a full range of tree responses: species and genetic diversity, physiology, survival, growth, and product/wood quality

- Determine the effects of silvicultural practices on a range of abiotic environmental factors: microclimate, soil moisture, nutrient cycling, floral diversity, and wildlife habitat (vegetation structure and composition)

- Develop an accurate, defensible database that can be used with other research and monitoring information to calibrate stand-scale models that will accurately forecast allowable cut, and ecological and economic viability

\section{Experimental design}

The NEBIE plot network was originally designed to include eight independent, randomized, complete block experiments referred to as NEBIE sites near Sioux Lookout, Dryden, Thunder Bay, Wawa, Kapuskasing, Timmins, North Bay, and Petawawa, Ontario (Fig. 1). At each site, a range of forest management intensities were applied as treatments (Fig. 2). Treatments (i.e., silviculture intensities; see Table 1 for descriptions) were replicated four times on each site. Several areas in the plot network were not harvested as intended, resulting in fewer than the planned four replications. The North Bay site was reduced to three replications; the Thunder Bay and Wawa sites have one replication. Experimental plots of each treatment measure $100 \mathrm{~m}$ x $200 \mathrm{~m}$ (2 ha) including a 
Table 1. Objectives and criteria for success for the range of silviculture intensities applied in the Ontario NEBIE plot network (adapted from Bell et al. 2000, Park and Wilson 2007, and Bell et al. 2008)

\begin{tabular}{|c|c|c|}
\hline Intensity & Objective(s) & Criteria for success \\
\hline Natural (N) & - No human interventions & $\begin{array}{l}\text { Forest ecosystem responds (e.g., to fire, insects, and disease) without } \\
\text { human interventions }\end{array}$ \\
\hline Extensive (Ex) & - Manipulate species composition & $\begin{array}{l}\text { Stocking of desired tree species is greater than } 40 \% \text { and desired tree } \\
\text { species are free of major insect pests }\end{array}$ \\
\hline Basic (B) & $\begin{array}{l}\text { - Manipulate species composition } \\
\text { - Achieve full site occupancy }\end{array}$ & $\begin{array}{l}\text { Stocking of desired tree species is greater than } 60 \% \text { and desired tree } \\
\text { species are free of inter-specific competition and major insect pests }\end{array}$ \\
\hline Intensive (I) & $\begin{array}{l}\text { - Manipulate species composition } \\
\text { - Achieve full site occupancy } \\
\text { - Control density to optimize individual } \\
\text { tree growing space }\end{array}$ & $\begin{array}{l}\text { Stocking of desired tree species is greater than } 80 \% \text { and desired tree } \\
\text { species are free from inter- and intra-specific competition and major } \\
\text { insect pests }\end{array}$ \\
\hline Elite (El) & $\begin{array}{l}\text { - Manipulate species composition } \\
\text { - Achieve full site occupancy } \\
\text { - Control density to optimize individual } \\
\text { tree growing space } \\
\text { - Achieve higher product value, and/or } \\
\text { ameliorate site productivity }\end{array}$ & $\begin{array}{l}\text { Stocking of desired tree species is greater than } 80 \% \text { and desired tree } \\
\text { species are free from inter- and intra-specific competition, nutrient } \\
\text { deficiencies, and major insect pests }\end{array}$ \\
\hline
\end{tabular}

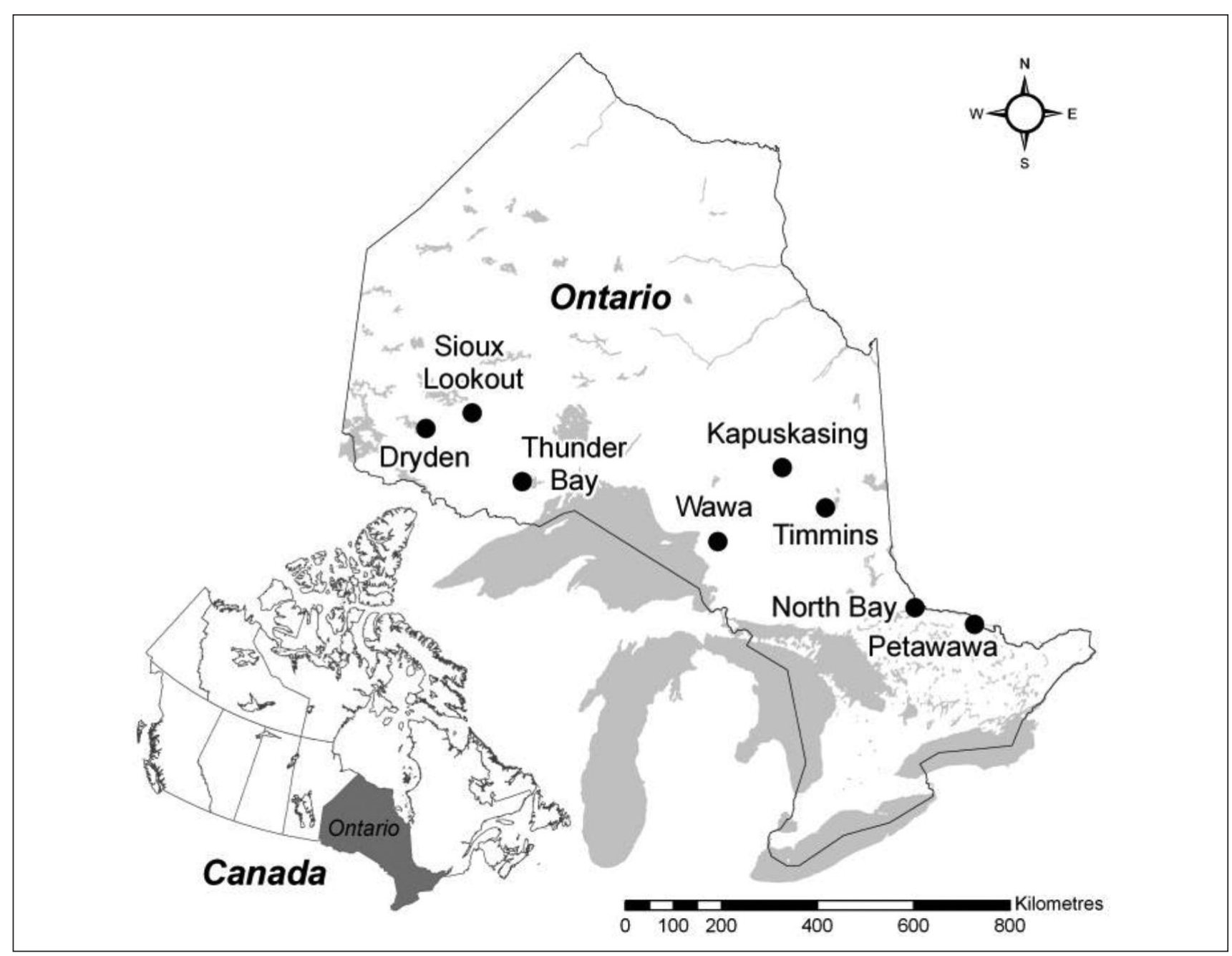

Fig. 1. Location of the NEBIE plot network sites within Ontario, Canada. 


\section{Extensive}

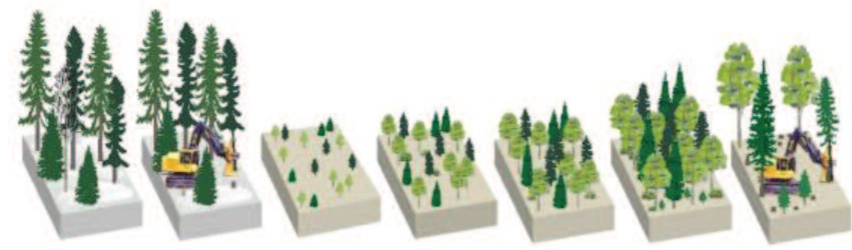

Basic

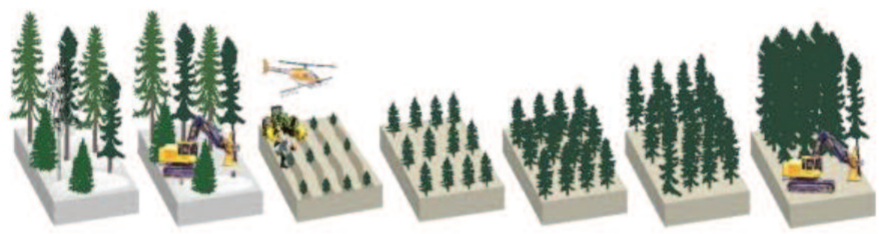

Intensive
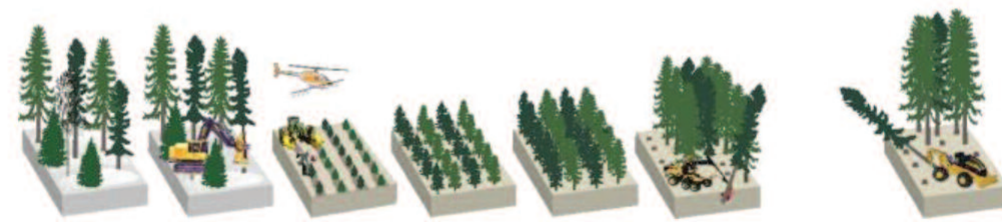

Elite
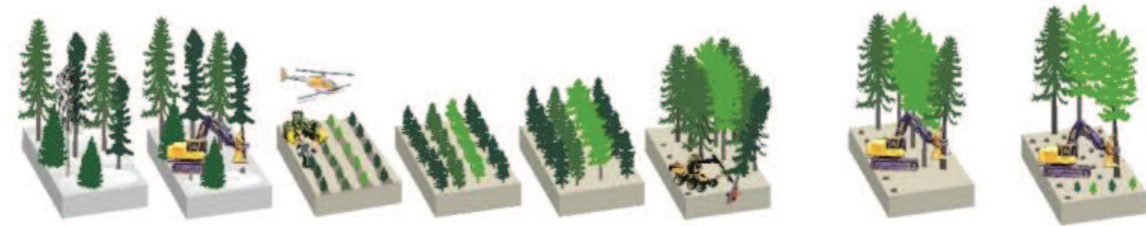

Fig. 2. Illustration of silviculture prescriptions for the Dryden, Ontario (boreal mixedwood) site of the NEBIE plot network. (Each shift to the right represent and increment of about one decade). Thus the elite treatment could be commercial thinned and harvested in the $4^{\text {th }}$ and $8^{\text {th }}$ decade post-establishment, respectively.

$20 \mathrm{~m}$ buffer zone (white squares in Fig. 3). To accommodate sampling needs, all experimental plots were divided into destructive and non-destructive sampling zones. To ensure that researchers would not be interfering with each other's work, 20 x 20 m sub-plots (grey squares in Fig. 3) were randomly assigned to specific types of monitoring (e.g., growth and yield, soils, biodiversity).

\section{Treatment design}

Site specific silviculture strategies that were hypothesized to achieve stand-scale objectives, e.g., enhancing fibre quantity, conserving biodiversity, maintaining soil and water quality, and contributing to economic development of each intensity level, were selected as treatments. Forest industry partners and researchers formulated detailed prescriptions using a crop planning approach (Day and Bell 1988, Willcocks et al. 1990). Several factors were considered when developing silviculture prescriptions including: (1) forest type, soils, and silviculture intensity; (2) species and genetic composition of the desired future stand; (3) availability of resources (light, nutrients, and water) to crop trees versus other vegetation that contributes to biodiversity and wildlife habitat; (4) protection from fire, insects, disease, and severe weather; and, (5) utilization standards for desired future crop trees.

The clear cut and seed tree retention systems were applied to boreal conifer and boreal mixedwood stands, respectively. The shelterwood system (see Smith et al. 1997) was applied to northern temperate hardwood and northern temperate mixedwood stands (Appendix A). Attempts were made to retain biodiversity in all forests. For example, multiple species were planted: black spruce (Picea mariana [Mill.] B.S.P.), white spruce ( $P$. glauca [Moench] Voss), and white pine (Pinus strobus L.) in elite treatments at Dryden, and Canada yew (Taxus canadensis Marsh.) at North Bay. Guidelines for emulating natural disturbance patterns (OMNR 2001), i.e., a minimum of 25 stems ha $^{-1}$ left unharvested (Fig. 3), were applied at all but the boreal conifer site. Residual strips and patches were retained during site preparation and release treatments. The use of artificial regeneration ensured near complete implementation of the regeneration phase of a silviculture intensity at most sites. However, implementation of natural regeneration on the Petawawa site was delayed due to late occurrence of an abundant seed crop (see Bell 2015 for details). 


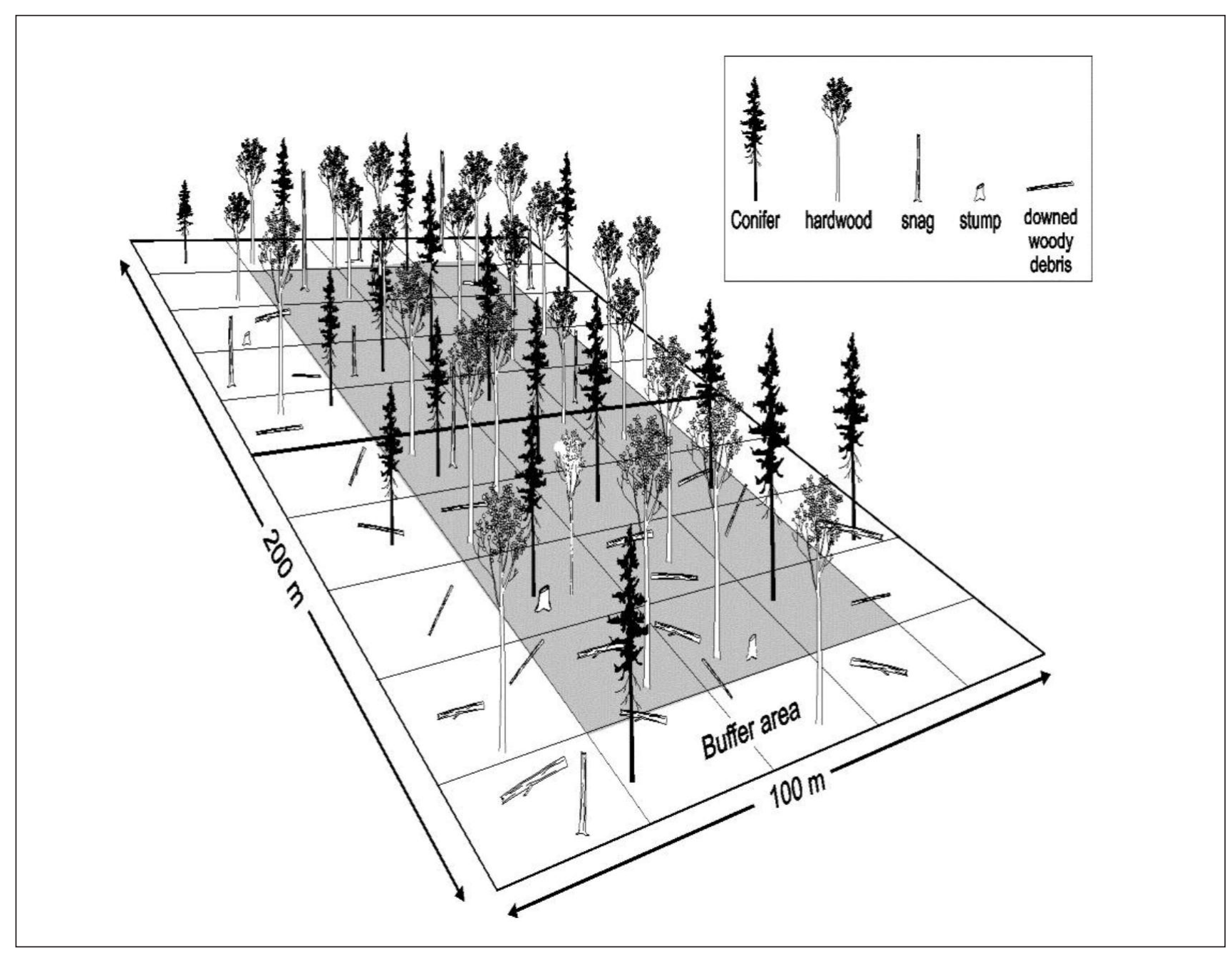

Fig. 3. Schematic of standard plot layout at all sites that illustrates post-harvest natural disturbance pattern emulation at the Kapuskasing, Ontario site.

Undisturbed forest plots are randomly located as a treatment within each block and referred to as natural disturbance or natural plots. The goal for the natural disturbance plots was to have a disturbance applied (i.e., prescribed fire) at the same time as the sites were being harvested to enable a comparison of results from the various silviculture options with those from forests regenerated following natural disturbance. However, disturbance was not implemented and the plots have been left untreated. These "controls" provide a reference for treatment effects and a baseline for resistance and resilience research.

\section{NEBIE sites}

The sites within the NEBIE plot network span $45^{\circ} 58^{\prime}$ to $50^{\circ}$ $0^{\prime} \mathrm{N}$, and $77^{\circ} 26^{\prime}$ to $92^{\circ} 46^{\prime} \mathrm{W}$, within a geographic area measuring $300 \mathrm{~km}$ north-south and $1100 \mathrm{~km}$ east-west. The sites are distributed across a broad climatic gradient in several forest types with differing natural disturbance regimes (Table 2 ). They include a northern temperate hardwood site near North Bay; a northern temperate mixedwood site near Petawawa; three boreal mixedwood sites near Timmins, Kapuskasing, and Dryden; and a boreal conifer site near
Sioux Lookout, Ontario. Due to operational constraints, the boreal hardwood sites near Thunder Bay and Wawa were not fully implemented.

Average daily temperatures in the study area range from 0.7 to $4.3^{\circ} \mathrm{C}$ and annual rainfall varies between 517 and $775 \mathrm{~mm}$. Soils vary greatly among sites with depths ranging from 40 to $>120 \mathrm{~cm}$, average organic matter depth from 1.8 to $7.4 \mathrm{~cm}$, and soil moisture regime from moderately dry to very moist. Effective textures, the substrate texture deemed to have the greatest influence on substrate moisture regime and drainage, were determined by field sampling in 2011. The effective soil textures are mainly sandy at the Sioux Lookout site, coarse loamy at the Dryden, Petawawa, and North Bay sites, clayey at the Kapuskasing site, and silty at the Timmins site.

\section{Sioux Lookout}

The Sioux Lookout site is located $35 \mathrm{~km}$ east of Sioux Lookout, Ontario $\left(50^{\circ} 01^{\prime} \mathrm{N}, 91^{\circ} 28^{\prime} \mathrm{W}\right)$, on Crown land in the boreal forest region of Canada (Rowe 1972). In 2002 when the site was harvested, it was dominated by a 90 -year-old jack pine (Pinus banksiana Lamb.) stand with a few pockets of black spruce. It was an even-aged, fire-origin stand classified 


\begin{tabular}{|c|c|c|c|c|c|c|c|c|}
\hline \multirow[b]{3}{*}{ Broad forest type } & \multicolumn{8}{|c|}{ Sites } \\
\hline & $\begin{array}{l}\text { Sioux } \\
\text { Lookout } \\
(\mathrm{SL})\end{array}$ & $\begin{array}{l}\text { Kapuskasing } \\
\text { (Kap) }\end{array}$ & $\begin{array}{l}\text { Timmins } \\
\text { (Tim) }\end{array}$ & $\begin{array}{l}\text { Dryden } \\
\text { (Dry) }\end{array}$ & $\begin{array}{l}\text { Petawawa } \\
\text { (Pet) }\end{array}$ & $\begin{array}{l}\text { North Bay } \\
\text { (NB) }\end{array}$ & $\begin{array}{l}\text { Thunder } \\
\text { Bay (TB) }\end{array}$ & Wawa \\
\hline & $\begin{array}{l}\text { Boreal } \\
\text { conifer }\end{array}$ & $\begin{array}{c}\text { Boreal } \\
\text { mixedwood }\end{array}$ & $\begin{array}{c}\text { Boreal } \\
\text { mixedwood }\end{array}$ & $\begin{array}{c}\text { Boreal } \\
\text { mixedwood }\end{array}$ & $\begin{array}{l}\text { Northern } \\
\text { temperate } \\
\text { conifer }\end{array}$ & $\begin{array}{l}\text { Northern } \\
\text { temperate } \\
\text { hardwood }\end{array}$ & $\begin{array}{c}\text { Boreal } \\
\text { hardwood }\end{array}$ & $\begin{array}{c}\text { Boreal } \\
\text { hardwood }\end{array}$ \\
\hline Mean precipitation $(\mathrm{mm})$ & )$^{\mathrm{a}} 716.1$ & 831.8 & 831.3 & 705.4 & 853.4 & 1007.7 & 764.6 & 1002.2 \\
\hline Mean rainfall $(\mathrm{mm})^{\mathrm{a}}$ & 517.2 & 544.6 & 558.1 & 565.8 & 651.4 & 774.6 & 565.7 & 727.4 \\
\hline Mean daily temp. $\left({ }^{\circ} \mathrm{C}\right)^{\mathrm{a}}$ & 1.6 & 0.7 & 1.3 & 1.8 & 4.3 & 3.8 & 2.3 & 1.7 \\
\hline Soil texture ${ }^{\mathrm{b}}$ & $\begin{array}{l}\mathrm{mS}_{7} \mathrm{LcS}_{1} \\
\mathrm{LmS}_{1} \mathrm{fS}_{1}\end{array}$ & $\mathrm{SiC}_{5} \mathrm{C}_{5}$ & $\begin{array}{l}\mathrm{SiL}_{7} \mathrm{Si}_{2} \\
\mathrm{SivfS}_{1}\end{array}$ & $\begin{array}{c}\mathrm{LmS}_{2} \mathrm{C}_{2} \mathrm{~L}_{2} \\
\mathrm{CL}_{1} \mathrm{LfS}_{1} \\
\mathrm{SiSS}_{1} \mathrm{SiL}_{1}\end{array}$ & $\begin{array}{l}\mathrm{L}_{4} \mathrm{SiL}_{2} \mathrm{SifS}_{2} \\
\operatorname{SimS}_{1} \mathrm{mSL}_{1}\end{array}$ & $\begin{array}{c}\mathrm{CL}_{2} \mathrm{mS}_{2} \\
\mathrm{SifS}_{1} \mathrm{mSL}_{1} \\
\mathrm{CS}_{1} \mathrm{~L}_{1} \\
\mathrm{SimS}_{1} \mathrm{fS}_{1}\end{array}$ & $\mathrm{SiCL}_{2}{ }_{2} \mathrm{~L}_{2}$ & $\mathrm{~S}_{10}$ \\
\hline Soil depth range ${ }^{c}$ & $\begin{array}{l}\text { moderately } \\
\text { deep to deep }\end{array}$ & deep & $\begin{array}{l}\text { moderately } \\
\text { deep to deep }\end{array}$ & $\begin{array}{l}\text { moderate } \\
\text { to deep }\end{array}$ & $\begin{array}{l}\text { moderate } \\
\text { to deep }\end{array}$ & deep $\mathrm{m}$ & $\begin{array}{l}\text { moderately no data } \\
\text { deep to deep }\end{array}$ & \\
\hline Silviculture system & clearcut & $\begin{array}{l}\text { seed tree } \\
\text { with } \\
\text { residuals }\end{array}$ & $\begin{array}{l}\text { seed tree } \\
\text { with } \\
\text { residuals }\end{array}$ & $\begin{array}{l}\text { seed tree } \\
\text { with } \\
\text { residuals }\end{array}$ & $\begin{array}{c}2 \text { crown } \\
\text { spacing } \\
\text { shelterwood }\end{array}$ & $\begin{array}{c}1 \text { and } 2 \\
\text { crown } \\
\text { spacing } \\
\text { shelterwood }\end{array}$ & $\begin{array}{l}\text { seed tree } \\
\text { with } \\
\text { residuals }\end{array}$ & $\begin{array}{l}\text { seed tree } \\
\text { with } \\
\text { residuals }\end{array}$ \\
\hline
\end{tabular}

anformation obtained from Environment Canada website: "http://climate.weatheroffice.gc.ca/climate_normals/index_e.html” (accessed August 2011).

bSoil texture codes: S-sand or sandy, Si-silt or sitly, L-loam or loamy, C-clay, vc-very coarse, c-coarse, m-medium, f-fine, vf-very fine.

'Soil depth classes ( $\mathrm{cm}$ of mineral material): moderate $>30$ to $60 \mathrm{~cm}$, moderately deep $>60$ to $120 \mathrm{~cm}$, deep $>120 \mathrm{~cm}$;

as site class 2. The understory was mainly composed of black spruce, red-stemmed feather moss (Pleurozium schreberi (Brid.) Mitt.), blueberry (Vaccinium myrtilloides Michx. and V. angustifolium Ait.), and creeping snowberry (Gaultheria hispidula [L.] Muhl. ex Bigelow).

Sandy soils over rolling bedrock with varying amounts of gravel and cobbles derived from esker and ground moraine landforms, (see Northern Ontario Engineering Geology Terrain Study [NOEGTs]), occur at the site. The effective texture is mainly medium sand, with areas of loamy coarse and medium sand, silty fine sand, and fine sand also occurring. The moisture regime is moderately dry with smaller areas of moderately fresh soil. The drainage class is rapid with very rapid and well drained soils less common. The humus form is mainly a moder, on average $5.8 \mathrm{~cm}$ thick (st. dev. $2.4 \mathrm{~cm}, \mathrm{n}=20$ ).

\section{Dryden}

The Dryden site is located approximately $30 \mathrm{~km}$ southeast of Dryden, Ontario $\left(49^{\circ} 38^{\prime} \mathrm{N}, 92^{\circ} 46^{\prime} \mathrm{W}\right)$, on Crown land in the boreal forest region of Canada (Rowe 1972). In 2005 when the site was harvested, it was dominated by black spruce and trembling aspen (Populus tremuloides Mich.) ranging in age from 64 to 104 years. It was a combination of site class 1 and 2 stands, with minor components of other species including paper birch (Betula papyrifera Marsh.), white spruce, balsam fir (Abies balsamea [L.] Mill.), red pine (Pinus resinosa Ait.), and eastern white pine (Pinus strobus L.). Common species in the understory include mountain maple (Acer spicatum
Lam.), raspberry (Rubus pubescens Raf. and R. idaeus L. ssp. strigosus [Michx.] Focke), and red-stemmed feather moss.

The soil at this site is derived from glaciolacustrine and glaciofluvial deposits (Source: NOEGTS) and is highly variable due to the undulating bedrock that dominates the area. The most common effective textures at the site are loamy medium sand, clay, and loam. Moisture regimes range from moderately dry to very moist with a fresh regime most common. The site drainage, in order of most to least common, is imperfect, well-drained, very rapid, and moderately welldrained. The organic matter is on average $4.8 \mathrm{~cm}$ thick (st. dev. $2.6 \mathrm{~cm}, \mathrm{n}=20$ ) with a moder humus form.

\section{Thunder Bay}

The Thunder Bay site is located $75 \mathrm{~km}$ northwest of Thunder Bay, Ontario (Block $1-48^{\circ} 47^{\prime} \mathrm{N}, 89^{\circ} 53^{\prime} \mathrm{W}$ ), on Crown land in the boreal forest region of Canada (Rowe 1972). Block 1 is included in the plot network as it was fully harvested in 2008; Block 2 was partially harvested and Blocks 3 and 4 remain unharvested. Tree species that occurred on Block 1 pre-harvest included trembling aspen, paper birch, balsam fir, spruce, and jack pine. The understory included mountain maple, wild sarsaparilla (Aralia nudicaulis L.), balsam fir, and bush honeysuckle (Diervilla lonicera Mill.).

Morainal deposits (Source: NOEGTS) over a bedrock knob influence the soil. The dominant effective texture is silty loam with silty clay loam and loam also present. The moisture regime at the site is fresh, with areas of moderately fresh and 
very fresh regimes. The site is well-drained. On average the depth of organic matter is $1.6 \mathrm{~cm}$ (st. dev. $1.4 \mathrm{~cm}, \mathrm{n}=5$ ) with mor humus forms most common.

\section{Kapuskasing}

The Kapuskasing site is located approximately $45 \mathrm{~km}$ southeast of Kapuskasing, Ontario $\left(49^{\circ} 09^{\prime} \mathrm{N}, 82^{\circ} 28^{\prime} \mathrm{W}\right)$, on Crown land in the boreal forest region of Canada (Rowe 1972). It was a mixed hardwood stand that established after an 1895 fire. Several tree species occurred on the site including balsam poplar (Populus balsamifera L.), trembling aspen, white spruce, paper birch, black spruce, and balsam fir. The understory included balsam fir, speckled alder (Alnus incana subsp. rugosa [Du Roi] R.T. Claus.), red raspberry, and largeleaved aster (Eurybia macrophylla [L.] Cass.).

Overall, the soil is fairly uniform, representing conditions typical of glaciolacustrine plains and ground moraine landforms (Source: NOEGTS) in the northeastern Ontario clay belt. The effective textures at the site are calcareous silty clay and clay. The site ranges from very fresh to very moist with very fresh and moist being the most common conditions. The drainage class is moderately well and imperfect. Moder and mor humus forms are present with an average organic matter depth of $7.4 \mathrm{~cm}$ (st. dev. $5.5 \mathrm{~cm}, \mathrm{n}=20$ ).

\section{Timmins}

The Timmins site is located approximately $15 \mathrm{~km}$ south of Timmins, Ontario $\left(48^{\circ} 21^{\prime} \mathrm{N}, 81^{\circ} 18^{\prime} \mathrm{W}\right)$, on Crown land in the boreal forest region of Canada (Rowe 1972). When the site was harvested in 2002, the stand age was 85 to 90 years, with tree species including trembling aspen, white spruce, paper birch, balsam poplar, balsam fir, black spruce, and jack pine. Common species in the understory included largeleaved aster, beaked hazelnut (Corylus cornuta Marsh.), speckled alder, and raspberry. Generally uniform, deep silty soils derived from a glaciolacustrine plain (Source: NOEGTS) are present.

Silty loam is the most common effective texture with areas of silt, silty fine and very fine sand, and silty clay loam also occurring. There are many clay lenses at depth. Moisture regimes range from moderately fresh to very moist, with fresh and moderately moist conditions most common. The site is mainly imperfectly drained with well and moderately welldrained areas also present. The organic matter is on average $3.1 \mathrm{~cm}$ deep (st. dev. $2.5 \mathrm{~cm}, \mathrm{n}=20$ ) when present, with mull and moder humus forms.

\footnotetext{
Wawa

The Wawa site is located approximately $70 \mathrm{~km}$ southeast of Wawa, Ontario (Blocks 1 and $2-47^{\circ} 47^{\prime} \mathrm{N}, 84^{\circ} 20^{\prime} \mathrm{W}$, Blocks 3 and $4-47^{\circ} 40^{\prime} \mathrm{N}, 84^{\circ} 27^{\prime} \mathrm{W}$ ), on Crown land in the transition between the boreal and Great Lakes-St. Lawrence (GLSL) forest regions of Canada (Rowe 1972). The site is a mixedwood stand. This site is not being assessed as part of the NEBIE plot network because Block 1 was only partially harvested in 2002 and all other blocks remain unharvested. Common tree species found on the site include paper birch, sugar maple (Acer saccharum Marsh.), red maple (Acer rubrum L.), balsam fir and yellow birch. The most common species in the understory include sugar and red maple, eastern bracken fern (Pteridium aquilinum [L.] Kuhn var. latiusculum [Desv.] Underw. ex A. Heller), balsam fir, and wild sarsaparilla.
}

The Wawa site is situated on a bedrock knob with areas of till from ground morainal deposits (Source: NOEGTS). The site has moderate local relief with areas of jagged, rugged, or cliffed topography. The soil is dry, fine to coarsely textured sand with approximately $5 \mathrm{~cm}$ of organic matter.

\section{North Bay}

The North Bay site is located approximately $50 \mathrm{~km}$ east of North Bay, Ontario (Block $3-46^{\circ} 22^{\prime} \mathrm{N}, 79^{\circ} 00^{\prime} \mathrm{W}$ ), on Crown land in the GLSL forest region of Canada (Rowe 1972). In 2004 when the site was harvested, it was a tolerant hardwood stand dominated by sugar maple, yellow birch (Betula alleghaniensis Britt.), and red maple aged 104 to 130 years. Evidence of prior logging was visible. Other tree species included American beech (Fagus grandifolia Ehrh.), eastern hemlock (Tsuga canadensis [L.] Carr.), and paper birch. Understory species included sugar maple, yellow birch, spinulose wood fern (Dryopteris carthusiana [Vill.] H.P. Fuchs), and hobblebush (Viburnum lantanoides Mich.).

Rolling morainal deposits (Source: NOEGTS) with variable soil depth dominate the site. Dominant effective soil textures include clay loam, medium sand, silty fine sand, medium sandy loam, and coarse sand. The moisture regime ranges from moderately dry to moderately moist with fresh to very fresh regimes most common. Drainage classes at the site range from very rapid to imperfect with well-drained soils most frequent. The humus form is a moder with an average organic matter thickness of $1.9 \mathrm{~cm}$ (st. dev. $1.1 \mathrm{~cm}, \mathrm{n}=15$ ) when present.

\section{Petawawa}

The Petawawa site is located approximately $20 \mathrm{~km}$ northwest of Petawawa, Ontario (Block $1-45^{\circ} 59^{\prime} \mathrm{N}, 77^{\circ} 28^{\prime} \mathrm{W}$ ), on the federally owned Petawawa Research Forest in the GLSL forest region of Canada (Rowe 1972). When harvested in 2005, the site was an 80 to 115 year old mixedwood stand that comprised eastern white pine, red maple, balsam fir, trembling aspen, red pine, and white spruce. There was no evidence of previous logging activities. Understory species included balsam fir, red maple, and beaked hazel.

Coarse loamy morainal deposits (Source: NOEGTS) of varying depths over bedrock are found at the Petawawa site. The main effective texture is loam, with silty loam, silty fine sand, silty medium sand, and medium sandy loam also present. Moderately fresh and very fresh are the most common moisture regimes with moderately dry, fresh, and moderately moist conditions also present. The site is well to moderately well-drained with areas of rapid and imperfect drainage. The organic matter averages $3.6 \mathrm{~cm}$ thick (st. dev. $1.7 \mathrm{~cm}, \mathrm{n}=20$ ) with a moder humus form.

\section{Summary}

The NEBIE plot network is designed to support evaluation of the suitability and sustainability of intensive forest management practices across a range of ecological regions in Ontario. While silviculture treatments have been previously evaluated, the NEBIE plot network does this at a much broader scale, and with a wider range of intensities, across a variety of common forest types. At this stage of the project, the experimental design has been established at six of eight sites. Although extensive and basic silvicultural intensities are fully implemented, additional treatments will need to be carried out 
(e.g., thinning) before the intensive and elite treatments are fully implemented.

\section{Acknowledgements}

We thank the Ontario Ministry of Natural Resources and Forestry (MNRF), Upper Lakes Environmental Research Network, University of Guelph, Canadian Ecology Centre-Forestry Research Partnership (CEC-FRP), and Forest Ecosystem Science Co-op (FESC) for supporting and comanaging the NEBIE plot network. The network was supported by financial grants from the Living Legacy Trust (LLT), Forestry Futures Trust (FFT)'s Enhanced Forest Productivity Science Fund, National Science and Engineering Research Council of Canada (NSERC), the Canada Foundation for Innovation/Ontario Innovation Trust, and Campbell Scientific.

We gratefully acknowledge the dedication and support provided by Clergue Forest Management Inc., Domtar Inc., EACOM Timber Corporation Inc., FPInnovations - FERIC Division, Green Forest Management Inc., Natural Resources Canada-Canadian Forest Service (CFS), Nipissing Forest Resource Management Inc., Resolute Forest Products (formerly Abi-Bow), Tembec Inc., and Weyerhaeuser Inc.

We are indebted to Chad Anderson, Peter Arbour, Robert Auld, Don Bazeley, Bill Cole, Steve D’Eon, Parthena Fotiadis, Rick Groves, Mark Hall, Janet Lane, John Lawson, Jeff Leach, Tom MacLean, Andree Morneault, Glen Niznowski, Tom Noland, John Parton, Dan Samis, Al Stinson, Peter Street, Bill Towill, John Winters, and Nikki Wood for their roles in developing and implementing harvesting and silviculture activities presented in Appendix A.

We are indebted to Sharon Cuddy and Dianne Miller for management of LLT funds and FFT funds, respectively; Jim Baker, David DeYoe, and Dan Puddister for administrative support within MNRF; Doug Pitt for advice on experimental design; John Winters, Monique Wester, Ray Ferguson, Amy Bolduc, Mya Rice and many others for installation of the plot network; and Lisa Buse, Nelson Thiffault, Laird Van Damme and Monique Wester for reviewing and commenting on earlier versions of this manuscript.

\section{References}

Bell, F.W. 2015. Effects of intensification of silviculture on plant diversity in northern temperate and boreal forests of Ontario, Canada. Sch. Environ. Sci., Univ. Guelph, Guelph, ON. PhD Diss. $408 \mathrm{p}$.

Bell, F.W., J. Parton, N. Stocker, D. Joyce, D. Reid, M. Wester, A. Stinson, G. Kayahara and B. Towill. 2008. Developing a silvicultural framework and definitions for use in forest management planning and practice. Forest. Chron. 84: 678-693.

Bell, F.W., J. Dacosta, S.G. Newmaster, A. Mallik, S. Hunt, M. Anand, J. Maloles, C. Peng, J. Parton, J. McLaughlin, J. Winters, M. Wester, and M. Shaw. 2017. The NEBIE plot network: Highlights of long-term scientific studies. Forest. Chron. (in Press).

Bell, F.W., D.G. Pitt, M. Irvine, B. Parker, L. Buse, N. Stocker, B. Towill, H. Chen, F. Pinto, K. Brown, D. DeYoe, T. McDonough, G. Smith and M. Weber. 2000. Intensive forest management science workshop summary. Ont. Min. Nat. Resour., Sault Ste. Marie, ON. Sci. Dev. Trans. Ser. No. 003. 45 p.

Carpenter, S.R., 1998. The need for large-scale experiments to assess and predict the response of ecosystems to perturbation. pp. 287-312 In: Pace, M.L. and P.M. Groffman (eds.). Successes, Limitations and Frontiers in Ecosystem Science. Springer-Verlag, NY.
Day, R.J. and F.W. Bell. 1988. Development of crop plans for hardwood and conifer stands on boreal mixedwood sites. In: Management and Utilization of Northern Mixedwoods. Can. For. Serv., North. For. Cent., Edmonton, AB. Info. Rep. NOR-X-296. p. 87-98. Franklin, J.F. 1989. Importance and justification of long-term studies in ecology. pp. 3-19 In G.E. Likens (ed.). Long-term Studies in Ecology: Approaches and Alternatives. Springer-Verlag, New York, NY

Fu, S., F.W. Bell, and H.Y.H. Chen, 2007. Long-term effects of intensive silvicultural practices on productivity, composition, and structure of northern temperate and boreal plantations in Ontario, Canada. Forest Ecol. Manage 241: 115-126.

Kimball, A.J. and M.L., Hunter. 1990. Intensive silviculture. pp. 200-234 In: M.L. Hunter, Jr. (ed.) Wildlife, Forests, and Forestry. Prentice Hall Career \& Technol., Englewood Cliffs, NJ.

Lautenschlager, R. A., F. W. Bell, R.G. Wagner, and P. E. Reynolds, 1998. The Fallingsnow Ecosystem Project: Documenting the consequences of conifer release alternatives. J. For. 96(11): 20-27.

Lieffers, V.J., C. Messier, P.J. Burton, J.-C. Ruel, and B.E. Grover. 2003. Nature-based silviculture for sustaining a variety of boreal forest values. pp. 481-530 In: Burton, P.J., C. Messier, D.W. Smith, and W.L. Adamowicz (eds.). Towards Sustainable Management of the Boreal Forest. NRC Research Press, Ottawa, ON.

MacDonald, G.B., J.A. Rice, J. McLaughlin, J. Pearce, L. Venier, K. Nystron, and P. Meek. 2003. Developing sustainable mixedwood practices in a stand-level adaptive management (SLAM) framework: Project establishment. Ont. Min. Nat. Resour., Ont. For. Res. Inst., Sault Ste. Marie, ON. For. Res. Inf. Pap. No. 157. 17 p.

[OFAAB] Ontario Forest Accord Advisory Board. 2002. Room to grow: Final report of the Ontario Forest Accord Advisory Board on implementation of the Accord. Ont. Min. Nat. Resour., Sault Ste Marie, ON. Final Rep. 28 p.

[OMNR] Ontario Ministry of Natural Resources. 1999. Ontario's Living Legacy land use strategy. Ont. Min. Nat. Resour., Toronto, ON. 136 p.

[OMNR] Ontario Ministry of Natural Resources. 2001. Forest management guide for natural disturbance pattern emulation, Version 3.1. Ont. Min. Nat. Resour., Toronto, ON. 40 p.

Roberts, M.R. and F.S. Gilliam, 1995. Patterns and mechanisms of plant diversity in forested ecosystems: Implications for forest management. Ecol. Applic. 5(4): 969-977.

Rowe, J.S. 1972. Forest regions of Canada. Can. For. Serv. Publ. 1300.

Smith, D.M., B.C. Larson, M.J. Kelty, P.M.S. Ashton. 1997. The Practice of Silviculture: Applied Forest Ecology. John Wiley, New York, NY., USA.

Tobner, C.M., A. Paquette, P.B. Reich, D. Gravel, and C. Messier, 2014. Advancing biodiversity-ecosystem functioning science using high-density tree-based experiments over functional diversity gradients. Oecologia 144: 609-621. DOI 10.1007/s00442-2815-4.

Urli, M., N. Thiffault, M. Barrette, and D. Chalifour. 2017. Key ecosystem attributes and productivity of boreal stands 20 years after the onset of silviculture scenarios of increasing intensity. Forest Ecol. Manage. 389: 404-416.

Volney, W.J.A., J.R. Spence, M.G. Weber, D.W. Langor, K.I. Mallet, J.D. Johnson, I.K. Edwards, G.R. Hillman, and B.E. Kishchuk. 1999. Assessing components of ecosystem integrity in the EMEND experiment. pp. 244-249 In: Veeman, T.S., D.W. Smith, B.G. Purdy, F.J. Salkle, and G.A Larkin (eds.), Proc. 1999 sustainable forest management network conference: Science and Practice: Sustaining the Boreal Forest, 14-17 February, 1999. University of Alberta, Edmonton, AB.

Wang, S. and H.Y.H. Chen. 2010. Diversity of northern plantations peaks at intermediate management intensity. Forest Ecol. Manage. 259: $360-366$

Willcocks, A.J., W. Bell, J. Williams, and P.N. Duiker. 1990. A crop planning process for northwestern Ontario: Determining stand silvicultural ground rules responsive to the objectives of the forest. Ont. Min. Nat. Resour., NW. Ont. For. Tech. Dev. Unit, Tech. Rep. \#30. 159 p. 


\section{Appendix A: Silviculture plans by site within the NEBIE plot network}

Table A1. Objectives and silvicultural activities for the Sioux Lookout Ontario NEBIE site

\begin{tabular}{|c|c|c|c|c|}
\hline & Extensive & Basic & Intensive & Elite \\
\hline Objectives & $\begin{array}{l}>40 \% \text { stocking } \\
\text { of any species, } \\
\text { free of major } \\
\text { insect pests }\end{array}$ & $\begin{array}{c}\mathrm{Pj} \text { and Sb stocking } \\
>60 \%, \text { free of } \\
\text { interspecific } \\
\text { competition and } \\
\text { major insect pests }\end{array}$ & $\begin{array}{l}\mathrm{Pj} \text { and Sb stocking } \\
>80 \% \text {, free of intra- } \\
\text { and interspecific } \\
\text { competition and } \\
\text { major insect pests }\end{array}$ & $\begin{array}{c}\mathrm{Pj} \text { and Sb stocking } \\
>80 \% \text {, free of nutrient } \\
\text { deficiencies, intra- and } \\
\text { interspecific } \\
\text { competition and major } \\
\text { insect pests }\end{array}$ \\
\hline Harvest & \multicolumn{4}{|c|}{$\begin{array}{l}\text { Summer 2002: clear-cut, full tree logging to roadside, no residual trees left on the harvested } \\
\text { treatments }\end{array}$} \\
\hline $\begin{array}{l}\text { Site } \\
\text { preparation }\end{array}$ & \multicolumn{4}{|c|}{$\begin{array}{c}\text { May 2004: } 2 \text { string skidder configuration spaced at } 2 \mathrm{~m} \text {. Each string started } \\
\text { with a shark-finned barrel followed by a } 4 \mathrm{~m} \text { spiked anchor chain and } 1 \mathrm{~m} \\
\text { length of backhoe pads, } 0.5 \mathrm{~m} \text { wide. }\end{array}$} \\
\hline $\begin{array}{l}\text { Aerial } \\
\text { seeding }\end{array}$ & none & \multicolumn{3}{|c|}{$\begin{array}{l}\text { April 2005: aerial seed of jack pine at } 50,000 \text { seeds ha }^{-1} \text { onto a } 80 \mathrm{~cm}+\text { snow } \\
\text { layer }\end{array}$} \\
\hline $\begin{array}{l}\text { In-fill tree } \\
\text { plant }\end{array}$ & none & none & \multicolumn{2}{|c|}{$\begin{array}{c}\text { May 2007: in-fill } 9000 \text { jack pine seedlings with an } \\
\text { average of } 550 \text { trees }^{-1}\end{array}$} \\
\hline $\begin{array}{l}\text { Vegetation } \\
\text { management }\end{array}$ & none & none & none & none \\
\hline $\begin{array}{l}\text { Future } \\
\text { options }\end{array}$ & none & none & $\begin{array}{l}\text { pre-commercial and } \\
\text { commercial thin }\end{array}$ & $\begin{array}{l}\text { pre-commercial and } \\
\text { commercial thin, } \\
\text { fertilize }\end{array}$ \\
\hline
\end{tabular}

$\mathrm{Pj}=$ jack pine, $\mathrm{Sb}=$ black spruce 
Table A2. Objectives and silvicultural activities for the Dryden Ontario NEBIE site

\begin{tabular}{|c|c|c|c|c|}
\hline & Extensive & Basic & Intensive & Elite \\
\hline Objectives & $\begin{array}{l}>40 \% \\
\text { stocking of } \\
\text { any species, } \\
\text { free of major } \\
\text { insect pests }\end{array}$ & $\begin{array}{c}>60 \% \text { stocking of } \\
\mathrm{Pw}, \mathrm{Pr}, \mathrm{Pj}, \mathrm{Sb} \text {, and } \\
\mathrm{Sw} \text { free of } \\
\text { interspecific } \\
\text { competition and } \\
\text { major insect pests }\end{array}$ & $\begin{array}{c}>80 \% \text { stocking of } \\
\mathrm{Pw}, \mathrm{Pr}, \mathrm{Pj}, \mathrm{Sb} \text {, and } \\
\mathrm{Sw} \text { free of intra- and } \\
\text { interspecific } \\
\text { competition and } \\
\text { major insect pests }\end{array}$ & $\begin{array}{c}>80 \% \text { stocking of } \mathrm{Pw}, \\
\mathrm{Pr}, \mathrm{Pj}, \mathrm{Sb} \text {, and } \mathrm{Sw} \text { free } \\
\text { of nutrient deficiencies, } \\
\text { intra- and interspecific } \\
\text { competition and major } \\
\text { insect pests }\end{array}$ \\
\hline Harvest & \multicolumn{4}{|c|}{$\begin{array}{l}\text { March 2005: clear cut using full tree logging to roadside. Leave } 25 \text { trees ha }{ }^{-1} \text { (at least } 2 \text { white } \\
\text { spruce ha }{ }^{-1}\left[6 \text { in extensive] and } 5 \text { to } 6 \text { wildlife trees ha }{ }^{-1} \text { ) }\right.\end{array}$} \\
\hline $\begin{array}{l}\text { Site } \\
\text { preparation }\end{array}$ & None & $\begin{array}{l}\text { Oct. 2005: disk } \\
\text { trench at } 3 \mathrm{~m} \\
\text { spacing }\end{array}$ & \multicolumn{2}{|c|}{ Oct. 2005: disk trench at $2.5 \mathrm{~m}$ spacing } \\
\hline Tree plant & None & $\begin{array}{c}\text { May 2006: } 1200 \mathrm{Sb} \\
\mathrm{ha}^{-1}\end{array}$ & $\begin{array}{c}\text { May 2006: } 1250 \mathrm{Sb} \\
\mathrm{ha}^{-1} \text { and } 1250 \mathrm{Sw} \mathrm{ha} \\
1 \text { as } 2 \text { rows of } \mathrm{Sb} \\
\text { followed by } 2 \text { rows } \\
\text { of } \mathrm{Sw}\end{array}$ & $\begin{array}{l}\text { May 2006: } 1000 \mathrm{Sb} \mathrm{ha} \\
1,1000 \mathrm{Sw} \mathrm{ha}^{-1} \text { and } 500 \\
\text { fertilizer enhanced } \mathrm{Pw} \\
\text { ha }^{-1} \text { as } 2 \text { rows of } \mathrm{Sb}, 1 \\
\text { row of } \mathrm{Sw}, 1 \text { row of } \mathrm{Pw} \text {, } \\
\text { and } 1 \text { row of } \mathrm{Sw}\end{array}$ \\
\hline \multirow{2}{*}{$\begin{array}{l}\text { Vegetation } \\
\text { management }\end{array}$} & \multirow[t]{2}{*}{ None } & \multicolumn{3}{|c|}{$\begin{array}{l}\text { Aug. 2007: Broad cast ground spray of glyphosate to control broadleaved } \\
\text { trees and shrubs }\end{array}$} \\
\hline & & none & \multicolumn{2}{|c|}{ Aug. 2010: Backpack ground spray of glyphosate } \\
\hline Cleaning & & & \multicolumn{2}{|c|}{$\begin{array}{c}\text { Nov. 2011: Clean to } 2500 \text { stems ha }{ }^{-1} \text { with the } \\
\text { priority Pw, Pr, Pj, Sw, Sb, Bf and leave } 6 \\
\text { hardwood species ha } \text { ha }^{-1}\end{array}$} \\
\hline $\begin{array}{l}\text { Future } \\
\text { options }\end{array}$ & None & none & commercial thin & $\begin{array}{l}\text { commercial thin, apply } \\
\text { fertilizer }\end{array}$ \\
\hline
\end{tabular}

$\mathrm{Pj}=\mathrm{jack}$ pine, $\mathrm{Pr}=$ red pine, $\mathrm{Pw}=$ white pine, $\mathrm{Sb}=$ black spruce, $\mathrm{Sw}=$ white spruce 
Table A3. Objectives and silvicultural activities for the Kapuskasing Ontario NEBIE site

\begin{tabular}{|c|c|c|c|c|}
\hline & Extensive & Basic & Intensive & Elite \\
\hline Objectives & $\begin{array}{l}>40 \% \\
\text { stocking of } \\
\text { any species, } \\
\text { free of } \\
\text { major } \\
\text { insect pests }\end{array}$ & $\begin{array}{l}>60 \% \text { stocking } \\
\text { of } \mathrm{Sb} \text { and } \mathrm{Sw} \\
\text { free of } \\
\text { interspecific } \\
\text { competition and } \\
\text { major insect } \\
\text { pests }\end{array}$ & $\begin{array}{l}>80 \% \text { stocking of } \\
\text { genetically superior } \mathrm{Sb} \\
\text { and } \mathrm{Sw} \text { free of intra- and } \\
\text { interspecific competition } \\
\text { and major insect pests }\end{array}$ & $\begin{array}{l}>80 \% \text { stocking of } \\
\text { genetically superior } \mathrm{Sb} \\
\text { and } \mathrm{Sw} \text { free of nutrient } \\
\text { deficiencies, intra- and } \\
\text { interspecific competition } \\
\text { and major insect pests }\end{array}$ \\
\hline Harvest & \multicolumn{4}{|c|}{$\begin{array}{l}\text { Fall 2003: clear cut using full tree logging to roadside. Leave } 25 \text { trees ha }^{-1} \text { (at least } 5 \text { to } 6 \text { seed } \\
\text { trees and } 5 \text { to } 6 \text { wildlife trees } \text { ha }^{-1} \text { ) }\end{array}$} \\
\hline $\begin{array}{l}\text { Site } \\
\text { preparation }\end{array}$ & none & none & \multicolumn{2}{|c|}{ August 2004 - Aerial spray with Vision ${ }^{\circledR}$ herbicide } \\
\hline Tree plant & none & $\begin{array}{l}\text { May 2005: } \\
\text { regular } \mathrm{Sb} \text { and } \\
\mathrm{Sw} \text { at a } 2: 1 \\
\text { ratio, } 1.8 \mathrm{~m} \mathrm{x} \\
1.8 \mathrm{~m} \text { spacing, } \\
\text { approx. } 2400 \\
\text { trees ha }{ }^{-1} \\
\text { actually planted } \\
\end{array}$ & $\begin{array}{l}\text { May 2005: } \mathrm{Sb} \mathrm{F2} \\
\text { enhanced and } \mathrm{Sw} \mathrm{F} 1 \\
\text { regular at } 1: 1.5 \text { ratio, } 1.5 \\
\mathrm{~m} \text { x } 1.5 \mathrm{~m} \text { spacing, } \\
\text { approx. } 3200 \text { trees ha }^{-1} \\
\text { actually planted }\end{array}$ & $\begin{array}{c}\text { May 2005: Sb F2 } \\
\text { enhanced and Sw F1 } \\
\text { regular at 1:1.5 ratio, } 1.5 \\
\text { m x 1.5 m spacing, } \\
\text { approx. } 3000 \text { trees ha }{ }^{-1} \\
\text { actually planted, species } \\
\text { planted in rows for future } \\
\text { silviculture options }\end{array}$ \\
\hline Vegetation & & \multicolumn{3}{|c|}{ August 2006: Aerial spray Vision ${ }^{\circledR}$ herbicide } \\
\hline management & none & none & August 2010: Aerial & ay Vision $\AA$ herbicide \\
\hline $\begin{array}{l}\text { Refill tree } \\
\text { plant }\end{array}$ & none & \multicolumn{3}{|c|}{$\begin{array}{c}\text { May } 2007 \text { - refill selected spots with Sb (18,000 total), Basic spacing } 3.3 \mathrm{~m} \mathrm{x} \\
3.3 \mathrm{~m} \text {, Intensive and Elite spacing } 2.8 \mathrm{~m} \times 2.8 \mathrm{~m} .\end{array}$} \\
\hline $\begin{array}{l}\text { Future } \\
\text { options }\end{array}$ & none & none & $\begin{array}{l}\text { commercial thin } \\
\text { leaving large diameter } \\
\mathrm{Sw}\end{array}$ & $\begin{array}{c}\text { commercial thin leaving } \\
\text { large diameter } \mathrm{Sw}, \\
\text { fertilizer application, } \\
\text { pruning }\end{array}$ \\
\hline
\end{tabular}

$\mathrm{Sb}=$ black spruce, $\mathrm{Sw}=$ white spruce 
Table A4. Objectives and silvicultural activities for the Timmins Ontario NEBIE site

\begin{tabular}{|c|c|c|c|c|}
\hline & Extensive & Basic & Intensive & Elite \\
\hline Objectives & $\begin{array}{c}\text { stocking } \\
>40 \% \text { of any } \\
\text { species, free } \\
\text { of major } \\
\text { insect pests }\end{array}$ & $\begin{array}{c}\text { stocking }>60 \% \text { of } \\
\text { Sw, Sb and Po free } \\
\text { of interspecific } \\
\text { competition and } \\
\text { major insect pests }\end{array}$ & $\begin{array}{l}\text { stocking }>80 \% \text { of } \\
\text { Sw, Sb and Po free } \\
\text { of intra- and } \\
\text { interspecific } \\
\text { competition and } \\
\text { major insect pests }\end{array}$ & $\begin{array}{l}\text { stocking }>80 \% \text { of } \mathrm{Sw} \text {, } \\
\text { Sb and Po free of } \\
\text { nutrient deficiencies, } \\
\text { intra- and interspecific } \\
\text { competition and major } \\
\text { insect pests }\end{array}$ \\
\hline Harvest & \multicolumn{4}{|c|}{ 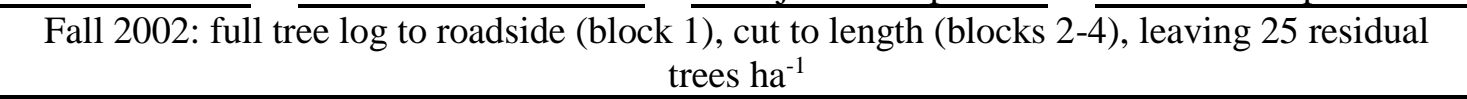 } \\
\hline $\begin{array}{l}\text { Site } \\
\text { preparation }\end{array}$ & none & $\begin{array}{l}\text { Sept. 2003: power } \\
\text { disc trench }\end{array}$ & \multicolumn{2}{|c|}{$\begin{array}{l}\text { Sept. 2003: power disc trench with second trench } \\
\text { pass at } 90^{\circ} \text { to the first pass } \\
\end{array}$} \\
\hline Tree plant & none & $\begin{array}{l}\text { Spring 2004: } 1800 \\
\text { white spruce ha } \\
\end{array}$ & \multicolumn{2}{|c|}{ Spring 2004: 2200 white spruce $\mathrm{ha}^{-1}$} \\
\hline $\begin{array}{l}\text { Vegetation } \\
\text { management } \\
\text { I }\end{array}$ & none & $\begin{array}{l}\text { Sept. 2005: back } \\
\text { pack application of } \\
\text { glyphosate to } \\
\text { control all } \\
\text { broadleaved trees } \\
\text { and shrubs } \\
\end{array}$ & $\begin{array}{l}\text { Sept. 2005: back } \\
\text { pack application of } \\
\text { glyphosate with } 3 \text { to } \\
6 \text { m wide no spray } \\
\text { strips } 27 \text { m apart }\end{array}$ & $\begin{array}{l}\text { Sept. 2005: back pack } \\
\text { application of } \\
\text { glyphosate leaving a } \\
\text { quality aspen every } 5 \\
\text { m }\end{array}$ \\
\hline $\begin{array}{l}\text { Vegetation } \\
\text { management } \\
\text { II }\end{array}$ & none & none & $\begin{array}{c}\text { Aug. 2007: back } \\
\text { pack application of } \\
\text { glyphosate with } 3 \text { to } \\
6 \text { m wide no spray } \\
\text { strips } 27 \text { m apart } \\
\end{array}$ & $\begin{array}{l}\text { Aug. 2007: back pack } \\
\text { application of } \\
\text { glyphosate leaving a } \\
\text { quality aspen every } 5 \\
\text { m }\end{array}$ \\
\hline $\begin{array}{l}\text { Re-fill tree } \\
\text { plant }\end{array}$ & none & $\begin{array}{c}\text { May 2008: } 583 \\
\text { white spruce ha }{ }^{-1} \\
\text { only block } 2\end{array}$ & $\begin{array}{l}\text { May 2008: } 730 \\
\text { white spruce } \text { ha }^{-1}\end{array}$ & $\begin{array}{l}\text { May 2008: } 1020 \text { white } \\
\text { spruce } \text { ha }^{-1}\end{array}$ \\
\hline $\begin{array}{l}\text { Future } \\
\text { options }\end{array}$ & none & none & commercial thin & $\begin{array}{l}\text { prune dead branches, } \\
\text { commercial thinning }\end{array}$ \\
\hline
\end{tabular}

$\mathrm{Po}=$ trembling aspen, $\mathrm{Sb}=$ black spruce, $\mathrm{Sw}=$ white spruce 
Table A5. Objectives and silvicultural activities for the Petawawa Ontario NEBIE site

\begin{tabular}{|c|c|c|c|c|}
\hline & Extensive & Basic & Intensive & Elite \\
\hline Objectives & $\begin{array}{c}>40 \% \\
\text { stocking } \\
\text { of all } \\
\text { species, } \\
\text { free of } \\
\text { major } \\
\text { insect } \\
\text { pests }\end{array}$ & $\begin{array}{c}>60 \% \text { stocking of } \\
\mathrm{Pw}, \mathrm{Pr} \text {, and Sw free } \\
\text { of interspecific } \\
\text { competition and } \\
\text { major insect pests }\end{array}$ & $\begin{array}{c}>80 \% \text { stocking of } \\
\mathrm{Pw}, \mathrm{Pr} \text {, and Sw free } \\
\text { of intra- and } \\
\text { interspecific } \\
\text { competition and } \\
\text { major insect pests }\end{array}$ & $\begin{array}{c}>80 \% \text { stocking of } \\
\text { Pw, Pr, and Sw, free } \\
\text { of nutrient } \\
\text { deficiencies, intra- } \\
\text { and interspecific } \\
\text { competition and } \\
\text { major insect pests }\end{array}$ \\
\hline
\end{tabular}

Harvest

Fall 2005 / winter 2006: harvest using Pw shelterwood system.

\begin{tabular}{|c|c|c|c|c|}
\hline $\begin{array}{l}\text { Post-harvest } \\
\text { cleaning salvage }\end{array}$ & \multicolumn{3}{|c|}{$\begin{array}{l}\text { Winter/spring 2007: salvage blowdown from severe windstorm } \\
\text { on July } 16,2006\end{array}$} & $\begin{array}{c}\text { Fall 2006: lop and } \\
\text { drop all uncut marked } \\
\text { trees and windthrown } \\
\text { trees. Winter/spring } \\
2007 \text { - salvage } \\
\text { blowdown from } \\
\text { severe windstorm on } \\
\text { July } 16,2006 \\
\end{array}$ \\
\hline $\begin{array}{l}\text { Post-harvest and } \\
\text { salvage basal area } \\
\left(\mathrm{m}^{2} / \mathrm{ha}\right)\end{array}$ & $\begin{array}{c}\text { total } 12.3 \\
\text { pine } 7.1\end{array}$ & $\begin{array}{c}16.9 \\
9.2\end{array}$ & $\begin{array}{l}15.2 \\
7.3\end{array}$ & $\begin{array}{l}12.5 \\
8.9\end{array}$ \\
\hline Site preparation & none & \multicolumn{3}{|c|}{$\begin{array}{c}\text { June to August 2007: Ground apply Vantage Plus Max }{ }^{\circledR} \text { herbicide by } \\
\text { skidder-mounted sprayer }\end{array}$} \\
\hline Infill tree plant & none & $\begin{array}{c}\text { May 2008: Block } 2 \\
\text { only }-1,750 \mathrm{Pw} \\
\text { (Zone } 30,3+0)\end{array}$ & $\begin{array}{c}\text { May 2008: Block } 2 \\
\text { only }-2,650 \mathrm{Pw} \\
(\text { Zone } 30,3+0)\end{array}$ & $\begin{array}{l}\text { May 2008: Blocks } 1 \\
\text { to } 4-\text { Sw (Zone } 36, \\
\text { G+1.5), } 1,000 \text { per } \\
\text { treatment plot, plant } \\
\text { in open pockets, } \\
\text { Block } 2 \text { only }-2,300 \\
\text { Pw (Zone } 30,3+0) \\
\end{array}$ \\
\hline $\begin{array}{l}\text { Vegetation } \\
\text { management }\end{array}$ & none & $\begin{array}{l}\text { Aug. 2008: Block } 4 \text {, } \\
\text { only - Ground appy } \\
\text { Vision }{ }^{\circledR} \text { in a } 1 \% \\
\text { solution by backpack } \\
\text { sprayer }\end{array}$ & \multicolumn{2}{|c|}{$\begin{array}{l}\text { Sept. 2010: Ground apply Release }{ }^{\circledR} \text { in a } 2 \% \\
\text { solution by backpack sprayer }\end{array}$} \\
\hline Refill plant & none & none & & \\
\hline Future options & & none & & $\begin{array}{l}\text { 2028: prune } 200 \mathrm{Pw} \\
\text { ha }^{-1} \text { at } 8 \text { to } 10 \mathrm{~cm} \\
\text { DBH based on market } \\
\text { evaluation, } 2034: \\
\text { commercial thin } \mathrm{Sw}\end{array}$ \\
\hline Overstory removal & none & Overs & emoval expected to o & in 2034 \\
\hline
\end{tabular}

$\mathrm{Pr}=$ red pine, $\mathrm{Pw}=$ white pine, $\mathrm{Sw}=$ white spruce 
Table A6. Objectives and silvicultural activities for the North Bay Ontario NEBIE site

\begin{tabular}{|c|c|c|c|c|}
\hline & Extensive & Basic & Intensive & Elite \\
\hline Objectives & $\begin{array}{c}>40 \% \\
\text { stocking of all } \\
\text { species, free } \\
\text { of major insect } \\
\text { pests }\end{array}$ & $\begin{array}{l}>60 \% \text { stocking } \\
\text { of By and Mh } \\
\text { free of } \\
\text { interspecific } \\
\text { competition and } \\
\text { major insect } \\
\text { pests }\end{array}$ & $\begin{array}{l}>80 \% \text { stocking } \\
\text { of By and Mh } \\
\text { free of intra- and } \\
\text { interspecific } \\
\text { competition and } \\
\text { major insect pests } \\
\text { to provide quality } \\
\text { stems for the } \\
\text { veneer market } \\
\end{array}$ & $\begin{array}{l}>80 \% \text { stocking of By and } \\
\text { Mh free of nutrient } \\
\text { deficiencies, intra- and } \\
\text { interspecific competition } \\
\text { and major insect pests. } \\
\text { Enhance opportunity for } \\
\text { non-timber products to } \\
\text { increase revenue. }\end{array}$ \\
\hline Harvest & $\begin{array}{c}\text { Fall 2004: } \\
\text { harvest using } \\
\text { shelterwood } \\
\text { system. } \\
\text { Harvest only } \\
\text { Crown Forest } \\
\text { Sustainability } \\
\text { Act grade } \\
\text { stems } \\
\end{array}$ & \multicolumn{2}{|c|}{$\begin{array}{l}\text { Fall 2004: harvest using shelterwood } \\
\text { system. Tree mark and cut all marked } \\
\text { trees } \geq 10 \mathrm{~cm} \text { diameter. Maintain } 15 \text { to } \\
20 \% \text { mid-tolerant (birch) species. }\end{array}$} & $\begin{array}{l}\text { Fall 2004: harvest using } \\
\text { shelterwood system. Tree } \\
\text { mark and cut all marked } \\
\text { trees } \geq 10 \mathrm{~cm} \text { diameter. } \\
\text { Selection cut to control } \\
\text { diseases. Maintain } 15 \text { to } \\
20 \% \text { mid-tolerant (birch) } \\
\text { species }\end{array}$ \\
\hline $\begin{array}{l}\text { Post-harvest } \\
\text { cleaning }\end{array}$ & none & none & $\begin{array}{c}\text { Fall 2005: } \\
\text { additional tree } \\
\text { marking and } \\
\text { remove } \\
\text { unmarketable and } \\
\text { diseased trees, } \\
\text { fell and buck into } \\
2.5 \text { m lengths } \\
\end{array}$ & $\begin{array}{l}\text { Fall 2005: additional tree } \\
\text { marking and remove } \\
\text { unmarketable and diseased } \\
\text { trees, fell and buck into } 1.25 \\
\text { m lengths }\end{array}$ \\
\hline $\begin{array}{l}\text { Post-harvest } \\
\text { and salvage } \\
\text { basal area } \\
\left(\mathrm{m}^{2} / \mathrm{ha}\right)\end{array}$ & $\begin{array}{c}\text { total } 19.6 \\
\text { By } 6.8\end{array}$ & $\begin{array}{c}11.9 \\
1.6\end{array}$ & $\begin{array}{c}16.0 \\
2.4\end{array}$ & $\begin{array}{l}11.4 \\
2.0\end{array}$ \\
\hline $\begin{array}{l}\text { Site } \\
\text { preparation }\end{array}$ & none & $\begin{array}{l}\text { Fall 2005: blade } \\
\text { by bulldozer with } \\
\text { multi-directional } \\
\text { blade to obtain } \\
21 \% \text { mineral soil } \\
\text { exposure }\end{array}$ & $\begin{array}{c}\text { Fall 2005: blade } \\
\text { by bulldozer with } \\
\text { multi-directional } \\
\text { blade to obtain } \\
51 \% \text { mineral soil } \\
\text { exposure } \\
\end{array}$ & $\begin{array}{l}\text { Fall 2005: blade by } \\
\text { bulldozer with multi- } \\
\text { directional blade to obtain } \\
56 \% \text { mineral soil exposure }\end{array}$ \\
\hline $\begin{array}{l}\text { Non-timber } \\
\text { values }\end{array}$ & none & none & none & $\begin{array}{c}\text { Aug. 2006: plant } 800 \\
\text { Canada yew } \\
\end{array}$ \\
\hline $\begin{array}{l}\text { Supplementar } \\
\text { y site } \\
\text { preparation }\end{array}$ & none & none & May 2008: Block 3 & $\begin{array}{l}\text { ly - reblade and seed with By } \\
\text { seed }\end{array}$ \\
\hline $\begin{array}{l}\text { Vegetation } \\
\text { management }\end{array}$ & none & none & none & none \\
\hline Future options & none & none & commercial thin & $\begin{array}{l}\text { commercial thin, apply } \\
\text { fertilizer, prune }\end{array}$ \\
\hline
\end{tabular}

By $=$ yellow birch, $\mathrm{Mh}=$ hard maple 
Table A7. Objectives and silvicultural activities for Block 1 at the Thunder Bay Ontario NEBIE site

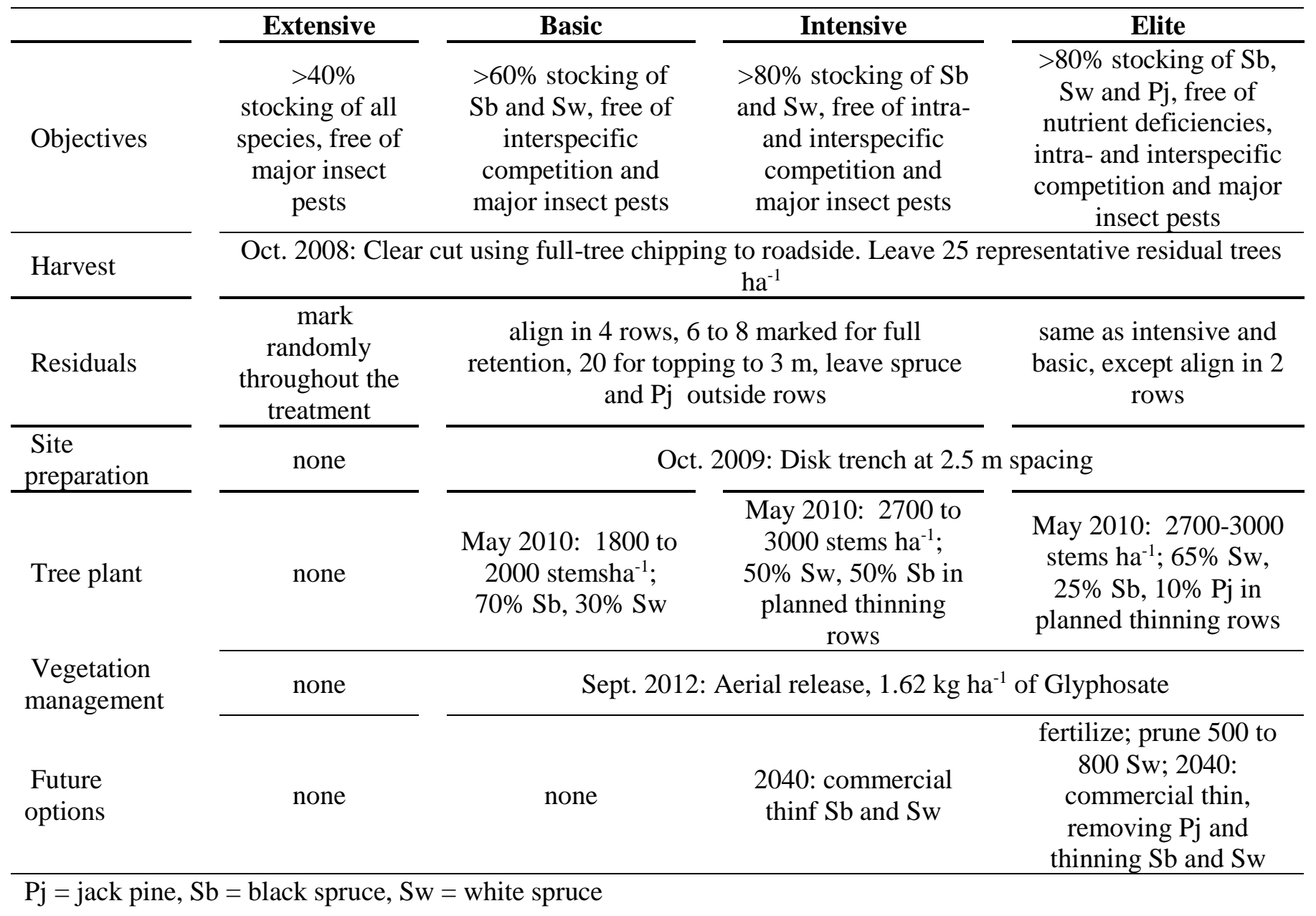


Table A8. Objectives and silvicultural activities for the Wawa Ontario NEBIE site

\begin{tabular}{|c|c|c|c|c|}
\hline & Extensive & Basic & Intensive & Elite \\
\hline Objectives & $\begin{array}{c}>40 \% \text { stocking } \\
\text { of all species, } \\
\text { free of major } \\
\text { insect pests }\end{array}$ & $\begin{array}{l}>60 \% \text { stocking of } \\
\text { Bp, free of } \\
\text { interspecific } \\
\text { competition and } \\
\text { major insect pests }\end{array}$ & $\begin{array}{c}>80 \% \text { stocking of } \\
\text { Bp, free of intra- and } \\
\text { interspecific } \\
\text { competition and } \\
\text { major insect pests }\end{array}$ & $\begin{array}{l}>80 \% \text { stocking of } \mathrm{Bp}, \\
\text { free of nutrient } \\
\text { deficiencies, intra- and } \\
\text { interspecific } \\
\text { competition and major } \\
\text { insect pests }\end{array}$ \\
\hline Harvest & \multicolumn{4}{|c|}{$\begin{array}{l}\text { 2003: Block 1, 2007: Block } 2 \text { - Clear cut using full tree to roadside. Leave } 25 \text { trees ha }{ }^{-1} \text { (at least } \\
5 \text { to } 6 \text { seed trees and } 5 \text { to } 6 \text { wildlife trees } \text { ha }^{-1} \text { ) }\end{array}$} \\
\hline Residuals & \multicolumn{4}{|c|}{$\begin{array}{l}\text { 2003: Mark for no harvest - } 10 \text { Bp seed trees, 15-20 other species, all Ce and Pw and a } 10 \mathrm{~m} \times 10 \\
\text { m clump of } \mathrm{Bf} \mathrm{ha}^{-1}\end{array}$} \\
\hline $\begin{array}{l}\text { Planned site } \\
\text { preparation }\end{array}$ & none & \multicolumn{3}{|c|}{$\begin{array}{l}\text { Light-medium straight blade, small machinery; hexazinone, max. } 3 \mathrm{~L} \\
\text { Velpar-Lha }{ }^{-1} \text {, backpack application }\end{array}$} \\
\hline $\begin{array}{l}\text { Planned } \\
\text { tree plant }\end{array}$ & none & \multicolumn{3}{|c|}{1400 to 1800 stems of $\mathrm{Bp} \mathrm{ha}^{-1}$} \\
\hline $\begin{array}{c}\text { Future } \\
\text { options }\end{array}$ & \multicolumn{3}{|c|}{ None } & fertilize, prune \\
\hline $\begin{array}{l}\text { Future } \\
\text { thinning }\end{array}$ & \multicolumn{2}{|c|}{ tone } & \multicolumn{2}{|c|}{ target 250 to 400 quality $\mathrm{Bp} \mathrm{ha}^{-1}$ final rotation } \\
\hline
\end{tabular}

$\mathrm{Bp}=$ paper birch 